\title{
Product Development of Mini Chamber with Ergonomic Function Deployment (EFD) Method
}

\author{
Rifqi Arief Adrianto ${ }^{1 *}$, Deden Wahyudi ${ }^{2}$, Dhesya Tiaramadhanti ${ }^{3}$, Jessica Marcelline Mesinay ${ }^{4}$, \\ Anita Juraida ${ }^{5}$
}

Department of Industrial Engineering, Widyatama University, Bandung, Indonesia

rifqi.arief@widyatama.ac.id ${ }^{1 *}$, deden.wahyudi@widyatama.ac.id², dhesya.tiaramadhanti@widyatama.ac.id ${ }^{3}$, jessica.marcelline@widyatama.ac.id ${ }^{4}$, anita.juraida@widyatama.ac.id ${ }^{5}$

Article History: Received:11 January 2021; Accepted: 27 February 2021; Published online: 5 April 2021

\begin{abstract}
Corona Virus Disease-19 (Covid-19) pandemic is still ongoing until now. The spread of this virus is very dangerous because it can spread through droplets or the particles that come out from the nose and mouth. Based on these sentences, the spread of the virus has become risky, one of the activities is shopping online. Virus transmission can occur through delivery and receive stuff activities. The habit that occurs in public, often the stuff arrived at home indirectly sterilized. The purpose of the research is to develop a product that can sterilize the stuff with disinfectant automatically. This research for product development with Ergonomic Function Deployment (EFD) Method. In this method, the product concept is designed based on customer needs (voice of customer). Data of customer needs is obtained from the result of 100 respondents with an age range of 20-40 years who frequently online shopping. The product designed refers to the method used with the ergonomic principle after data is processed. The recommendation of product development from this research is a mini chamber. This product is a development of the chamber but its function is for spraying stuff from the outside of house. The procedure of this product is works automatically so the application of this product for customer can be easier.
\end{abstract}

Keywords: Ergonomic function deployment, anthropometry, house of ergonomic, mini chamber, Covid-19

\section{Introduction}

At the end of 2019, China was recorded as the county with first virus cases suspected the virus has similarity with the pandemic was occurred in 17 years ago is SARS (Severe Acute Respiratory Syndrome). SARS is a case of the acute respiratory syndrome [1]. The virus is called Corona Virus Disease-19 or Covid-19. According to World Health Organization (WHO) in 2019, Covid-19 is an infectious virus caused by new viruses are SARS-CoV-2. This virus was transmitted by droplets or the particles form mouth that was produced when an infected has cough, sneezing, or exhales. These droplets are too heavy and cannot stay in the air, until dropped quickly stick on the floor or other surface. Corona Virus Disease-19 has many dangerous is a complication of respiratory tract. Patient death rate as result of this virus is showing exponential graphic.

In 2020 was reported have many countries had many efforts to avoid spreading this virus, including Indonesia. The severity rate showing that the risk suffered is high risk of death. The Ministry of Health of the Republic Indonesia issued the decision to implement health protocol. Many preventive efforts have promoted by Ministry of Health are maintaining distance, wearing a mask, washing the hand, and doing activities from home [2].

The goal of activities from home is to reduce of people crowding. The activities such as studying, working, and shopping form home. According to the Directorate-General of Post and Information (PPI) Ministry of Information and Communication, online sales in 2020 this pandemic is increased drastically until 400\% [3]. People interest for online shopping are increase drastically, but the people often have less aware of the stuff they bought before. Box of packaging was bought from online store are not guaranteed to clean. Viruses, which are the microorganisms, it can stick on the surface the boxes. The viruses can stay on the air for three hours until two days on the box and plastic.

To minimize that statement, many products are using to support Adaption of New Habit (AKB). For example, the product was designed from Faculty of Computer Science Mulia University Students is automatic hand sanitizer with robotic technology [4]. Furthermore, the innovation product from Malang State University Students is portable sink, both of products have same goals are making easier for people to apply new habit [5]. In this research, the product designed is product development of chamber. Using of chamber have pro and contra because the disinfectant effect for the users or people and the environment. However, the product developed for this research is mini chamber that is specifically to customer for spray the disinfectant 
automatically the stuff from house outside area. Customer can move mini chamber to the desired place and effective for using this product so there are no droplets are left on the stuff.

The existence of this product is helping to customer for avoid Covid-19 by stuff sterilizing process form the house outside area with disinfectant automatically. Working sensor will make it easier for customer to using this product and make it easier for customer to move the desired place. The product design based on Ergonomic Function Deployment (EFD) Method. This method is product development method that consider aspects ergonomic. The attributes for this research based on customer needs (voice of customer). With this research, is hope can be contributed to reduction spread rate of Covid-19. This product can also reference many people in effort to Adaptation of New Habit.

\section{Literature Review}

\subsection{Ergonomic}

Ergonomic is the study of human relation by seeing all the limitations that the people have goal for increasing productivity of works [6-7]. The aspects of ergonomic to achieving ENASE (Effective, Comfortable, Safety, Healthy, and Efficient). The explanation about ergonomic aspects are:

1. Effective, this aspect put forward the goal have been planned before.

2. Comfortable, this aspect stated that the condition to avoid the anxiety.

3. Safety, this aspect put forward free from risk or the things can be injured by people.

4. Health, this aspect is the condition who avoid from disease or health problem.

5. Efficient, this aspect is the achievement a goal has been planned before by considering all sides, from costs, power, and time spent.

\subsection{Product Development}

Product development is very important at the time that considering many products have made without pay attention the product function. The goal of product development is to make easier jobs and increasing in works both in the home environmental and in company environmental. The steps to starting product development are [8]:

a. Doing product planning

b. Identify about customer needs by doing collecting data according to the product want to design.

c. Give the decision for product specification so product designed can determine the components in this product.

d. The preparation of product concept must be seen form the design until work system that will use on customer.

e. The aim of concept product is to see and reassess product concept have been planned before based on customer needs.

f. Concept testing is carried out so customer needs have been planned before are fulfilled.

g. The design of product architecture is carried out based on product function that has made and makes the components of product.

h. The industry design applied ergonomic aspects to avoid from injury until the sense of secure to use this product.

i. The aim of design for a manufacture process has made is supporting the product has been designed before so that the product created can provide benefit or value to customer.

j. Creating a prototype, as a product description before the product will be manufacturing with dimension or actual size.

k. Economic analysis is very important to make decision whether the product is useful or not.

\subsection{Ergonomic Function Deployment (EFD)}

Ergonomic Function Deployment or EFD is development of the Quality Function Deployment (QFD) Method by applying from ergonomic aspect which is will develop the product [9]. EFD Method is used to give a decision for product development by connecting the attributes based on the product being designed [10]. The attribute elements used based on customer needs. The attribute designed must be contain ENASE elements (Effective, Comfortable, Safety, Health, and Efficient). The application of EFD Method is usually in industry, both of small scale and large scale, for example in company. 
The step in processing data for EFD Method have using the matrix, which is to connecting all of the other attributes. The matrix used to EFD Method called the House of Ergonomic (HOE). This is following the structure of House of Ergonomic (HOE) [11].

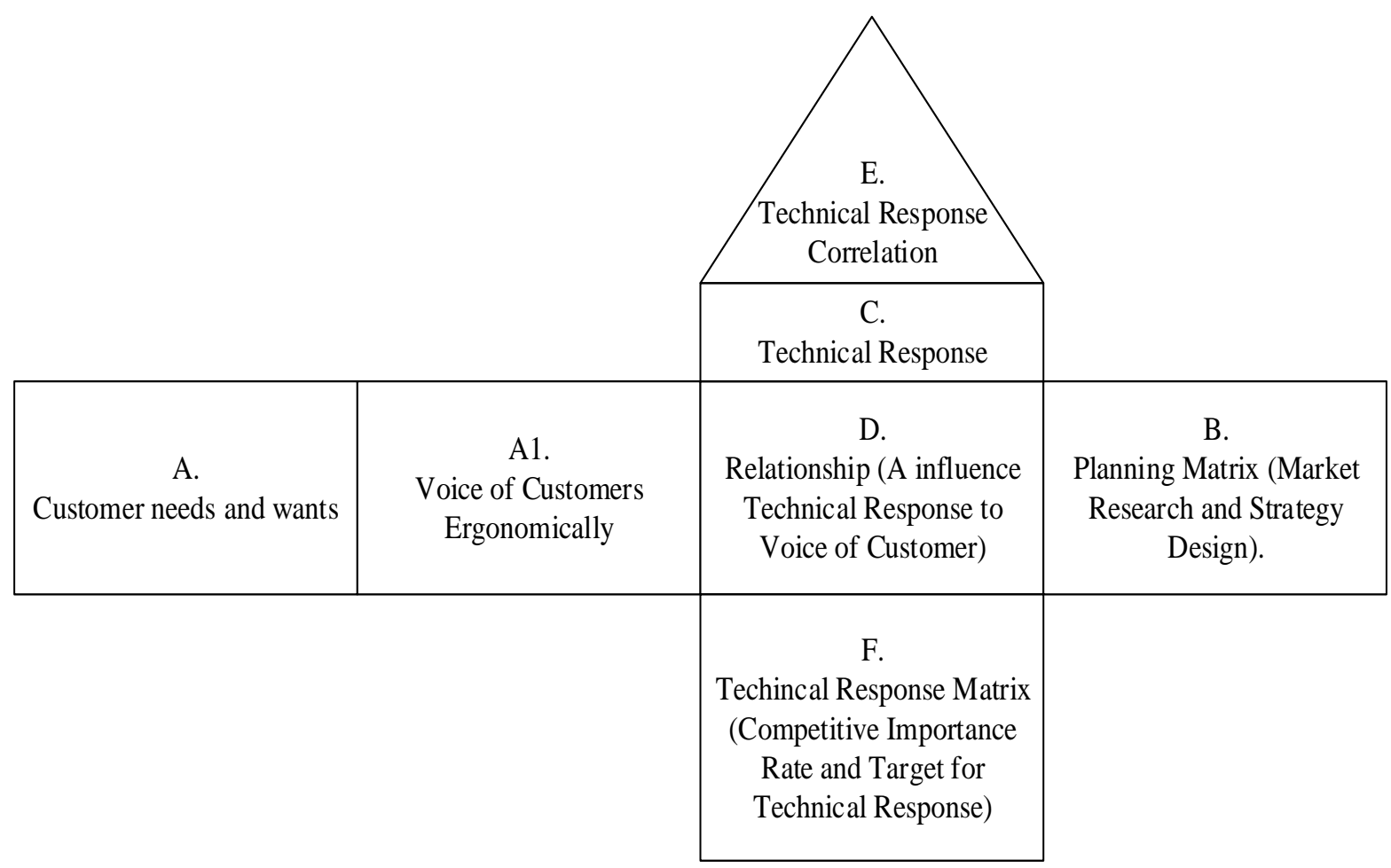

Figure 1. House of ergonomic (HOE)

\subsection{Anthropometry}

The term of Anthropometry comes from Greek with two words "Anthropos" is human and "metros" is measure [10]. Anthropometry is one of Method in Ergonomic to study the dimension of human body [12]. The implementation of Anthropometry in company is usually for designing or developing the product. The use of Anthropometry for products so avoid the users get injury, provide sense of secure and comfort when the user uses it. The dimension measure of human body is varying from other, but there are factors can affect dimension of human body. The factors on dimension of human body can be from age, gender, ethnic, body position, thickness or thinness clothes worn by human, disability, and pregnancy [13]. The data collection of Anthropometry based on product to designed.

\section{Methodology}

The Method used for this research is Ergonomic Function Deployment (EFD) Method with Anthropometry Method. This research is using primary data and secondary data. The collection data for Ergonomic Function Deployment (EFD) Method with primary data is a questionnaire. The questionnaire made contains have 15 statements with range in age 20 until 40 years old. The statements for a questionnaire contains ergonomic aspects are ENASE (Effective, Comfortable, Safety, Health, and Efficient). The respondents are required 100 respondents minimum. The parameter used with Likert Scale. In measurement, the form for opinion or agreement have five choices, are strongly disagree, disagree, neutral, agree, and strongly agree. The data is notated a number and then it processed. Next step is creating of House of Ergonomic (HOE) with connecting the attributes has been made by researcher and filled with respondents as customer. House of Ergonomic (HOE) finds out what the customer needs for product to be designed. After knowing what the customer needs, the determining of planning matrix and prioritization. After determining priorities, the next step is product design. The measure of the product based on Anthropometry dimension. Anthropometry Method is one of Method in Ergonomic id using for finds out product size based on dimension of human body. Determination of product is using with secondary data, is looking at https://antropometriindonesia.org/ and product sizes was designed based on percentile on each body dimension. Product planning made with software AutoCAD. 


\section{Results and Discussion}

\subsection{Data collection}

Product development currently needed for increasing productivity in a job. Product development planning is started form identifying customer needs (voice of customer) with a questionnaire was given to 100 respondents sample. Form the result obtained 15 attribute of customer needs. This is following is the voice of customer recapitulation:

Table 1. Voice of customer recapitulation

\section{Scale}

No.

Questions

$\begin{array}{lllll}1 & 2 & 3 & 4 & 5\end{array}$

\begin{tabular}{|c|c|c|c|c|c|c|}
\hline 1 & The mechanism of this product when it spraying the stuff automatically & 1 & 1 & 13 & 28 & 57 \\
\hline 2 & The spray right on the stuff so it can kill the virus & 1 & 2 & 9 & 17 & 71 \\
\hline 3 & The product have place to put the stuff for spraying process easily & 1 & 0 & 10 & 27 & 62 \\
\hline 4 & Product is designed based on dimension of human body size & 0 & 1 & 18 & 25 & 56 \\
\hline 5 & Have handle and wheels for customers to move a mini chamber easily & 0 & 1 & 8 & 33 & 58 \\
\hline 6 & The design of mini chamber with eye catching colour & 0 & 1 & 19 & 33 & 47 \\
\hline 7 & Product material made from harmless material & 0 & 0 & 4 & 20 & 76 \\
\hline 8 & There are not have sharp sides and corners in product & 0 & 0 & 7 & 26 & 67 \\
\hline 9 & Have lock valve in the refill to avoid leakage when refilling the disinfectant & 0 & 1 & 10 & 27 & 62 \\
\hline 10 & $\begin{array}{l}\text { Spaying the disinfectant to stuff can reduce the dangers of droplets from the } \\
\text { outside house area }\end{array}$ & 0 & 0 & 13 & 27 & 60 \\
\hline 11 & Disinfectant liquid just spreading in a mini chamber & 1 & 4 & 17 & 28 & 50 \\
\hline 12 & Have a great residue steam sewer & 1 & 0 & 14 & 23 & 62 \\
\hline 13 & Product design is simple so the product can stored in everywhere & 0 & 2 & 8 & 25 & 65 \\
\hline 14 & The spraying is carried out in a short times & 1 & 4 & 10 & 28 & 57 \\
\hline 15 & Product is designed can be charged with charger & 1 & 3 & 14 & 27 & 55 \\
\hline
\end{tabular}

\subsection{Data processing}

\subsubsection{Data adequacy test}

Data Adequacy Test is needed in this research for make sure the data has collected and presented adequacy on objective measurement.

$N^{\prime}=\left[\frac{k / s \sqrt{N \Sigma X^{2}-(\Sigma X)^{2}}}{\Sigma X}\right]^{2}=\left[\frac{40 \sqrt{100(30582)-44488900}}{49.78}\right]^{2}$

$\mathrm{N}^{\prime}<\mathrm{N}=49.78<1500$, so the data is adequate.

\subsubsection{Validity and reliability}

Validity is an accuracy test of an instrument in research [14]. The data obtained form 100 respondents is $n$ or the amount of data in research. Validity uses Pearson correlation coefficient ( $\mathrm{r}$ table) as a valid limit or not. The validity test is presented in Figure 2. 
Rifqi Arief Adrianto ${ }^{1 *}$, Deden Wahyudi ${ }^{2}$, Dhesya Tiaramadhanti ${ }^{3}$, Jessica Marcelline Mesinay ${ }^{4}$, Anita Juraida $^{5}$

\begin{tabular}{|l|r|r|r|r} 
& $\begin{array}{c}\text { Scale Mean if } \\
\text { Item Deleted }\end{array}$ & $\begin{array}{c}\text { Scale } \\
\text { Variance if } \\
\text { Item Deleted }\end{array}$ & $\begin{array}{c}\text { Corrected } \\
\text { Item-Total } \\
\text { Correlation }\end{array}$ & $\begin{array}{c}\text { Cronbach's } \\
\text { Alpha if Item } \\
\text { Deleted }\end{array}$ \\
\hline VAR00001 & 129.0100 & 238.717 & .695 & .745 \\
\hline VAR00002 & 128.8500 & 239.644 & .663 & .746 \\
\hline VAR00003 & 128.9100 & 241.113 & .657 & .748 \\
\hline VAR00004 & 129.0400 & 241.837 & .582 & .749 \\
\hline VAR00005 & 128.9200 & 241.428 & .713 & .748 \\
\hline VAR00006 & 129.1400 & 244.243 & .492 & .752 \\
\hline VAR00007 & 128.6800 & 245.957 & .653 & .753 \\
\hline VAR00008 & 128.8000 & 242.364 & .748 & .749 \\
\hline VAR00009 & 128.9000 & 239.303 & .781 & .745 \\
\hline VAR00010 & 128.9300 & 240.147 & .743 & .746 \\
\hline VAR00011 & 129.1800 & 240.412 & .546 & .748 \\
\hline VAR00012 & 128.9500 & 237.644 & .757 & .744 \\
\hline VAR00013 & 128.8700 & 239.165 & .773 & .745 \\
\hline VAR00014 & 129.0400 & 239.231 & .620 & .746 \\
\hline VAR00015 & 129.0800 & 238.276 & .653 & .745 \\
\hline
\end{tabular}

Figure 2. Validity test with SPSS software

The corrected item-total correlation value above is the calculation r-value which is greater than DF value (degree of freedom). The result of $r$ value is 0,1966 based on significance test is 0.05 . The calculation $r$-value is greater than table $r$, so the result is valid. The goal of reliability test is to determine the consistency whether the measure tool uses can be dependable and consistent.

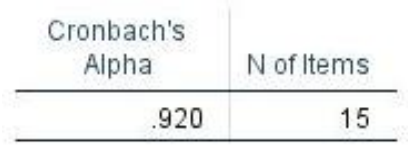

Figure 3. Reliability test with SPSS software

In this research, the data is processing and the result 0,920 , which is base of making decision based on Cronbach's Alpha is 0,6 . It is because Cronbach Alpha is greater than 0,6 so the data is reliable or consistent [15].

\subsubsection{Drafting of the house of ergonomic}

The drafting of House of Ergonomic is determined by making Planning Matrix are [16]: 1. Importance to Customer (ITC)

Importance to Customer is level of importance in each of attribute. The calculation of ITC with mode or the value has appeared frequently. In this research, the respondents are fulfilled the attribute with strongly agree opinion so the value has appeared frequently is 5,00 .

\section{Current Satisfaction Performance (CSP)}

Current Satisfaction Performance is the rating of satisfaction level from product development planning. The satisfaction level of customer can be calculated with formula:

Weight Average Performance $=\left(\sum \mathrm{i}[(\right.$ Number of respondents at performance value i).i) $)) /(($ Total number of respondents))

Weight Average Performance $=(439 / 100)=4,39$

3. Goal

The goal determination from researcher discussion based on an Importance to Customer. This assessment is based on subjective assessment which is the researcher was made target value will be achieved. Goal assessment scale shown from the below table: 
Table 2. Goal scale

\begin{tabular}{cc}
\hline Scale & Explanation \\
\hline 1 & Very unsatisfying \\
\hline 2 & Unsatisfying \\
\hline 3 & Neutral \\
\hline 4 & Satisfying \\
\hline 5 & Very Satisfying \\
\hline
\end{tabular}

4. Improvement Ratio (IR)

The Improvement Ratio is showing the amount of changing or improvement will be doing. In the mathematics form, value of Improvement Ratio is:

Improvement Ratio $=$ Goal/Current Satisfaction Performance

Improvement Ratio $=5 / 4,39=1,14$

The value is means for improvement; the explanation of meaning is:

Table 3. Scale improvement ratio

\begin{tabular}{cc}
\hline Value & Meaning \\
\hline$<1$ & No improvement \\
\hline $1,0-1,5$ & Moderate improvement \\
\hline$>1,5$ & Improvement completely \\
\hline
\end{tabular}

\section{Sales Point (SP)}

Sales Point is the amount of selling of product or consumption value in product development planning. Sales Point value shown from the below table:

Table 4. Sales point scale

\begin{tabular}{cc}
\hline Value & Meaning \\
\hline 1 & No sales point \\
\hline 1,2 & Moderate sales point \\
\hline 1,5 & Intense sales point
\end{tabular}

Sales Point selected is the subjective value of chosen based on the attributes, which is have highly sell rate.

6. Raw Weight (RW)

This step uses are showing the amount of improvement in customer need criteria. In the mathematics form, determine of value is:

Raw Weight $=$ Importance to Customer $x$ Improvement Ratio $x$ Sales Point

Raw Weight $=5,00 \times 1,14 \times 1,5=8,54$

7. Normalized Raw Weight (NRW)

NRW is the value from Raw Weight that is has made form $0-1$ scale, can be calculating with formula:

Normalized Raw Weight $=($ Raw Weight $) /($ Raw Weight Total $)$

Normalized Raw Weight $=8,54 / 104,81=0,082$

8. Relationship Matrix

This matrix used for showing the relation of cause and effect between customer needs and technical response. In mathematics form, the determined of Relationship Matrix is: 
Rifqi Arief Adrianto ${ }^{1 *}$, Deden Wahyudi ${ }^{2}$, Dhesya Tiaramadhanti ${ }^{3}$, Jessica Marcelline Mesinay ${ }^{4}$, Anita Juraida $^{5}$

Relationship Matrices $=$ Raw Weight Value $*$ Rating Weight of Relationship Level

Relationship Matrix rated based on the subjective value to show the intense relationship until weak between customer needs and technical response. The determination to show the relationship between each of customer needs and technical response shown from the below table:

Table 5. Relationship value

\begin{tabular}{ccc}
\hline Symbol & Numeric Value & Meaning \\
\hline$\triangle$ & 1 & Relationship probably \\
\hline$\bigcirc$ & 3 & Moderate relationship \\
\hline 0 & 9 & The relationship very intense \\
\hline
\end{tabular}

The drafting for House of Ergonomic presented from the below table:

Table 6. Planning matrix drafting

\begin{tabular}{|c|c|c|c|c|c|c|c|c|}
\hline No. & Question & ITC & CSP & GO & IR & SP & RW & NRW \\
\hline 1 & $\begin{array}{l}\text { The mechanism of this product when it } \\
\text { spraying the stuff automatically }\end{array}$ & 5 & 4,39 & 5 & 1,14 & 1,5 & 8,54 & 0,082 \\
\hline 2 & $\begin{array}{l}\text { The spray right on the stuff so it can kill the } \\
\text { virus }\end{array}$ & 5 & 4,55 & 4 & 0,88 & 1,2 & 5,27 & 0,050 \\
\hline 3 & $\begin{array}{l}\text { The product have place to put the stuff for } \\
\text { spraying process easily }\end{array}$ & 5 & 4,49 & 4 & 0,89 & 1,2 & 5,35 & 0,051 \\
\hline 4 & $\begin{array}{l}\text { Product is designed based on dimension of } \\
\text { human body size }\end{array}$ & 5 & 4,36 & 4 & 0,92 & 1,5 & 6,88 & 0,066 \\
\hline 5 & $\begin{array}{l}\text { Have handle and wheels for customers to } \\
\text { move a mini chamber easily }\end{array}$ & 5 & 4,48 & 5 & 1,12 & 1,5 & 8,37 & 0,080 \\
\hline 6 & $\begin{array}{l}\text { The design of mini chamber with eye catching } \\
\text { colour }\end{array}$ & 5 & 4,26 & 4 & 0,94 & 1,2 & 5,63 & 0,054 \\
\hline 7 & Product material made from harmless material & 5 & 4,72 & 5 & 1,06 & 1,5 & 7,94 & 0,076 \\
\hline 8 & $\begin{array}{l}\text { There are not have sharp sides and corners in } \\
\text { product }\end{array}$ & 5 & 4,6 & 5 & 1,09 & 1,5 & 8,15 & 0,078 \\
\hline 9 & $\begin{array}{l}\text { Have lock valve in the refill to avoid leakage } \\
\text { when refilling the disinfectant }\end{array}$ & 5 & 4,5 & 5 & 1,11 & 1,5 & 8,33 & 0,080 \\
\hline 10 & $\begin{array}{l}\text { Spaying the disinfectant to stuff can reduce the } \\
\text { dangers of droplets from the outside house } \\
\text { area }\end{array}$ & 5 & 4,47 & 5 & 1,12 & 1,5 & 8,39 & 0,080 \\
\hline 11 & $\begin{array}{l}\text { Disinfectant liquid just spreading in a mini } \\
\text { chamber }\end{array}$ & 5 & 4,22 & 4 & 0,95 & 1,2 & 5,69 & 0,054 \\
\hline 12 & Have a great residue steam sewer & 5 & 4,45 & 4 & 0,90 & 1,2 & 5,39 & 0,051 \\
\hline 13 & $\begin{array}{l}\text { Product design is simple so the product can } \\
\text { stored in everywhere }\end{array}$ & 5 & 4,53 & 4 & 0,88 & 1,2 & 5,30 & 0,051 \\
\hline 14 & The spraying is carried out in a short times & 5 & 4,36 & 5 & 1,15 & 1,2 & 6,88 & 0,066 \\
\hline 15 & $\begin{array}{l}\text { Product is designed can be charged with } \\
\text { charger }\end{array}$ & 5 & 4,32 & 5 & 1,16 & 1,5 & 8,68 & 0,083 \\
\hline
\end{tabular}

From the data was processed above, the House of Ergonomic matrix with Ergonomic Function Deployment Method. The results of Planning Matrix above are input to House of Ergonomic later. The value of Importance to Customer (ITC) shown on the left side table.

While, the value of Customer Satisfaction Performance, Improvement Ratio, Sales Point, Raw Weight, and Normalized Raw Weight shown on the right side table. In the middle of the table filled with Relationship Matrix, which is marked with symbols based on between customer needs and technical response. For top triangle on the House of Ergonomic Diagram filled with technical response correlation. In the bottom side, have integrity and priority levels. Priority level determined from the result is highest until lowest. 


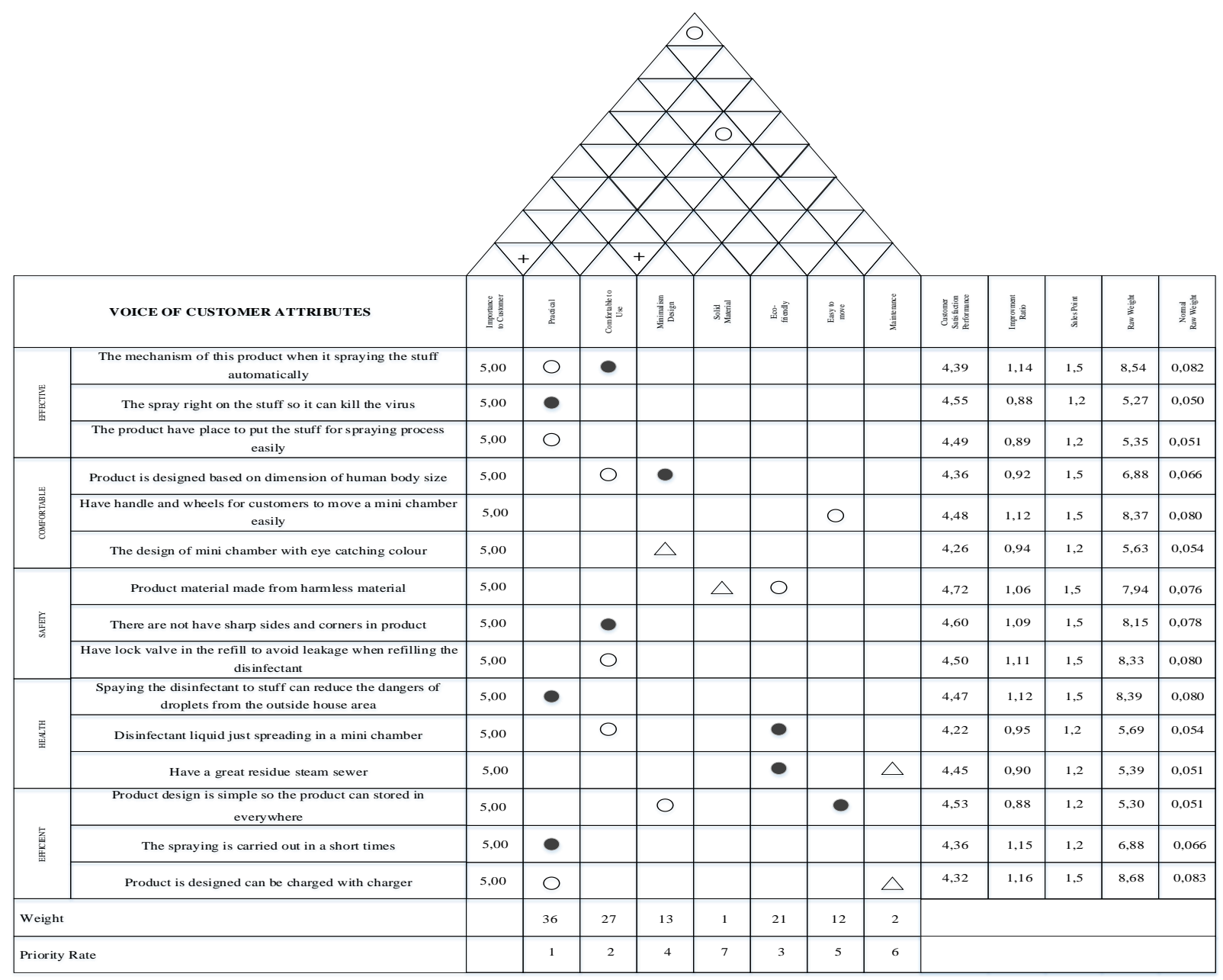

Figure 4. House of ergonomic

\subsubsection{Anthropometry}

In design, the product is needed to human body dimension in related with product specification. In anthropometry concept, percentile used as the base of measure for product [17]. The specification for P5 is used because the design of product specification, a critical for people who have small body posture. The product specification for P5 are handle width, width of a mini chamber product, height of a mini chamber product, length and weight of disinfectant refill. Meanwhile, P95 is critical for people who have a large body. The product specification for P95 are handle length, length of a mini chamber product, and height of disinfectant refill.

Table 7. Anthropometry dimension

\begin{tabular}{cccc}
\hline Specification & Dimension & Percentile & Size \\
\hline Handle length & D29 (Hand width) & P 95 & $15,87 \mathrm{~cm}$ \\
\hline Handle width & D28 (Hand length) & P 5 & $14,85 \mathrm{~cm}$ \\
\hline Length of a mini chamber product & D17 (Shoulder width) & P 95 & $50,89 \mathrm{~cm}$ \\
\hline Width of a mini chamber product & D23 (Forearm length) & P 5 & $31,00 \mathrm{~cm}$ \\
\hline Height of a mini chamber product & D15 (Knee height) & P 5 & $44,11 \mathrm{~cm}$ \\
\hline Length of disinfectant refill & D23 (Forearm length) & P 5 & $31,00 \mathrm{~cm}$ \\
\hline Width of disinfectant refill & D28 (Hand length) & P 5 & $14,85 \mathrm{~cm}$ \\
\hline Height of disinfectant refill & D29 (Hand width) & P 95 & $15,87 \mathrm{~cm}$ \\
\hline
\end{tabular}

From anthropometry data processing, so the researcher is designing a product with AutoCAD software as shown below: 


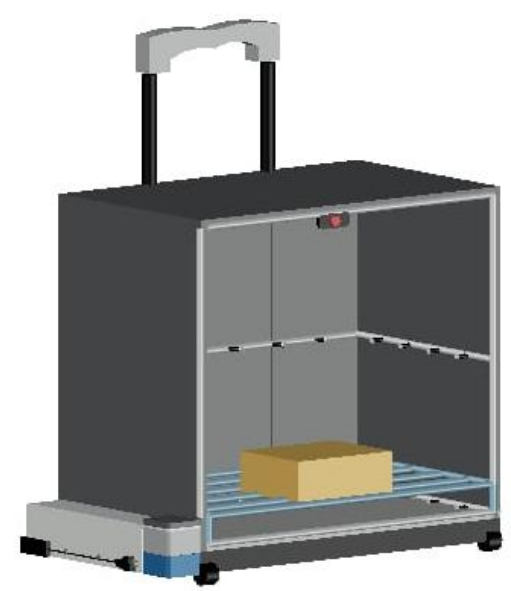

Figure 5. Mini chamber

\section{Results and Discussion}

Based on the result of research has been done, the data can see in Table 1 is voice of customer. From 100 respondents, the data shown as many as $60 \%$, the opinions are very agreeing of 15 voice of customer attributes have been given. Then, the data is processed and tested of adequacy data with validity and reliability. The data from 100 respondents is adequate. Likewise, validity and reliability test were the data collected and processed are valid and reliable.

After that, the data processed to planning matrix. The planning matrix is a base for processing a House of Ergonomic. One of the goal of House of Ergonomic is to know the voice of customer priority. Priority rate has seen in the bottom of House of Ergonomic. The first of priority rate is practical. In this priority, there are three voice of customers are the spray right on the stuff so it can kill the virus, spaying the disinfectant to stuff can reduce the dangers of droplets from the outside house area, and the spraying is carried out in a short time. The spraying carried out in 90 seconds, which is the nozzle was set in 30 seconds slowly for spraying the product [18].

The second priority is comfortable to use. This attribute has two voice of customers are the mechanism of this product when it spraying the stuff automatically and there are not have sharp sides and corners in product. The mechanism of this product when it spraying the stuff automatically because the product uses with sensor system is Arduino sensor. The namely of this sensor is Sensor Motion PIR HCSR501 Detector Infrared which is when there is movement form hand to put the stuff in a Mini Chamber, the disinfectant is spraying with nozzle automatically. The sensor installed on the top of product, it shown in Figure 6.

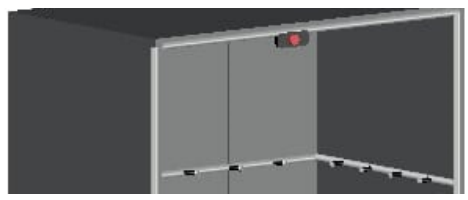

Figure 6. Sensor motion PIR HCSR501 detector infrared

The next voice of customer is there are not have sharp sides and corners in product. The shape of mini chamber designed is the corner of this product not to $90^{\circ}$ angle. This manifested by curving corner in product [19]. The principal applied of designing process give a $3 \mathrm{~cm}$ radius curves in the corner of product. The slight contouring in the corner of product have to increase of comfortable and aesthetic form the product.

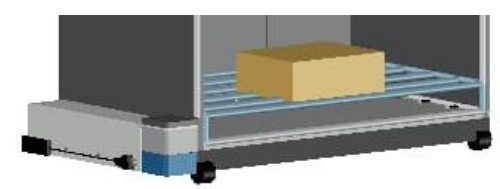

Figure 7. Disinfectant refill

The next priority is eco-friendly because the product made has pro and contra about the disinfectant. In Figure 7 shown disinfectant refill. The disinfectant liquid used in this product with the electrolyzed salt ion 
antiseptic (anolyte). Dr. Muji said the anolyte liquid can be sterilized in nose and throat during inhalation without difficulty breathing and skin irritation [20]. The salinity levels in 1-2\% salt can be optimized the disinfectant function [21].

Then, the needs for the product can moved easily. The product design was designed with additional handle and wheels so the product can be moved depends the customer. The other priorities used as a complement of product conceptual.

After determining the priorities, then production planning is designing with AutoCAD software. The size for a product while the product is designing with dimension of human body, it from Anthropometry Method in 20-40 years old. The size is using 5 percentile (P5) and 95 percentile (P95). P5 indicated the smallest size and P95 indicated the largest size. The goal of Anthropometry is the product assessment to maintain ergonomic principle in design or work system. With Ergonomic Function Deployment (EFD) Method, the design process of product conceptual used, ergonomic work system can be optimal based on voice of customer [22].

\section{Conclusion}

From the final result of research, the conclusion is voice of customers for a mini chamber can be applied ENASE principles are practical, comfortable to use, minimalist design, solid material, eco-friendly, easy to move, and maintenance. The data obtained from result of 100 respondents recapitulation. The product design based on result of House of Ergonomic Matrix. The size determined for product development is a range of 20-40 years with Ergonomic principle, which the goal is for designing ergonomically product in work system. With Ergonomic Function Deployment (EFD) Method, the design process of product can be optimal based on voice of customer.

\section{Acknowledgment}

Finally, the authors would like to thank everyone who helped the successful realization of this research. This research is expected to be useful not only for researchers, but also for readers. For this reason, constructive criticism and suggestions are welcome.

\section{References}

1. Handayani, D., Hadi, D. R., Isbaniah, F., Burhan, E., \& Agustin, H. (2020). Penyakit Virus Corona 2019. Jurnal Respirologi Indonesia, 40(2), 119-129.

2. Kementerian Kesehatan RI. 2020. KMK No. HK.01.07-MENKES-382-2020 tentang Protokol Kesehatan Bagi Masyarakat di Tempat dan Fasilitas Umum Dalam Rangka Pencegahan COVID-19. https://promkes.kemkes.go.id/kmk-no-hk0107-menkes-382-2020-tentang-protokol-kesehatan-bagimasyarakat-di-tempat-dan-fasilitas-umum-dalam-rangka-pencegahan-covid19.

3. CNN Indonesia. 2020. Belanja Online Naik 400 Persen Saat Musim Corona. https://www.cnnindonesia. com/ekonomi/20200707172450-92-521925/belanja-online-naik-400persen-saat-musim-corona.

4. Universitas Mulia. 2020. Hand Sanitizer Otomatis Karya Mahasiswa Fakultas Ilmu Komputer Universitas Mulia. https://universitasmulia.ac.id/2020/06/22/hand-sanitizer-otomatis-karya-mahasiswafakultas-ilmu-komputer-universitas-mulia/.

5. Kompasiana. 2020. Injak Lur: Wastafel Portable Buatan Mahasiswa UM Guna Cegah Sebaran Covid19. https://www.kompasiana.com/miftahuljannah6163/5f040012d541df6b9d4b3d43/injak-lur-wastafelportable-buatan-mahasiswa-um-guna-cegah-sebaran-covid-19.

6. Sumarningsih, T., Wibowo, M. A., \& Wardani, S. P. R. (2016). Ergonomics in work method to improve construction labor productivity. International Journal of Science and Engineering, 10(1), 3034

7. Pradani, W. R., Rahayu, M., Martini, S., \& Kurniawan, M. I. (2019). Design of Wood Pellets Carrier using Ergonomic Function Deployment (EFD) Approach to Increase Productivity of Work: A Research at PTPN VIII Ciater. IOP Conference Series: Materials Science and Engineering, 528(1), 012011.

8. Liansari, G. P., Febrianti, A., \& Gt, P. A. T. (2018). Usulan Rancangan House of Ergonomic (HOE) Produk Interior Toilet Gerbong Kereta Penumpang Kelas Ekonomi Menggunakan Metode Ergonomic Function Deployment (EFD). Penelitian dan Aplikasi Sistem dan Teknik Industri, 12(1), 328395.

9. Larisang, M. Ansyar Bora, and Antan Sadewa, "Pengembangan Alat Pelindung Diri Topi Sebo Pada Welder Dan Fitter di PT. Transalindo Eka Persada", Jurnal Industri Kreatif, vol 2, pp 33-39, 2018. 
10. El Ahmady, F. R., Martini, S., \& Kusnayat, A. (2020). Penerapan metode ergonomic function deployment dalam perancangan alat bantu untuk menurunkan balok kayu. Jurnal Integrasi Sistem Industri, 7(1), 21-30.

11. Liansari, G. P., Novirani, D., \& Subagja, R. N. (2016). Rancangan blueprint alat cetak kue balok yang ergonomis dengan metode ergonomic function deployment (EFD). Jurnal Rekayasa Sistem Industri, 5(2), 106-117.

12. Singh, S., Ahlawat, S., Pandya, S., \& Prafull, B. (2013). Anthropometric measurements and body composition parameters of farm women in north Gujarat. Journal of Ergonomics, 3(114), 2.

13. Liansari, G. P., Novirani, D., \& Subagja, R. N. (2016). Rancangan blueprint alat cetak kue balok yang ergonomis dengan metode ergonomic function deployment (EFD). Jurnal Rekayasa Sistem Industri, 5(2), 106-117.

14. Muhammad Qurthuby and Hari Purnomo, Usulan Desain Meja Komputer dengan Metode Quality Function Deployment. Seminar dan Konferensi Nasional IDEC, 2019.

15. Sahid Raharjo. 2019. Cara Melakukan Uji Reliabilitas Alpha Cronbach's dengan SPSS. https://www.spssindonesia.com/2014/01/uji-reliabilitas-alphaspss.html?m=1\#: :text=Adapun\%20dasar\%20pengambilan\%20keputusan\%20dalam,tidak\%20reliabel $\% 20$ atau $\% 20$ tidak\%20konsisten.

16. Wicaksono, A. W. (2013). Penerapan Metode QFD (Quality Function Deployment) Pada Rencana Pengembangan Sekolah Di SMKN 2 Yogyakarta. Skripsi, Universitas Negeri Yogyakarta.

17. Wibowo, R. K. K., Soekarno, S., Syuhri, A., \& Vayendra, D. D. (2018). Analysis and Design of Bus Chair for Economic Class Using Ergonomic Function Deployment (EFD) Method. International Journal of Advances in Scientific Research and Engineering, 4(10), 161-167.

18. Kementerian Kesehatan RI. 2020. Panduan Kegiatan Menjaga Kebersihan Lingkungan dan LangkahLangkah Desinfeksi dalam Rangka Langkah Pencegahan Penularan COVID-19. https://covid19.kemkes.go.id/download/Panduan_Desinfeksi_dalam_Rangka_Pencegahan_Penularan_ Covid19.pdf.

19. T. Yogasara and N. Hadikusuma, Perancangan Produk Telepon Genggam yang Sesuai dengan Keinginan Konsumen dan Prinsip-Prinsip Ergonomi. Seminar Nasional Product Design and Development, pp 21-36, 2003.

20. UNAIR News. 2020. Pakar UNAIR Inisiasi Pembuatan Anolyte Disinfektan yang Aman dan Ramah Lingkungan. http://news.unair.ac.id/2020/04/27/pakar-unair-inisiasi-pembuatan-anolyte-disinfektanyang-aman-dan-ramah-lingkungan/.

21. UKSW. 2020. Cegah Penularan Corona, Bilik Sterilisasi UKSW Gunakan Disinfektan Alami. https://www.uksw.edu/detail_post/news/cegah-penularan-corona-bilik-sterilisasi-uksw-gunakandisinfektan-alami.

22. Dwyantoro, M. A. G., \& Rahayu, M. (2019). Tool Design for Tea Cutting Machine to Reduce MSDs Using Ergonomic Function Deployment: A Research at PTPN 8 Ciater. International Conference on Industrial Enterprise and System Engineering, pp. 232-235. 